no sickness; no flatus. Distemsion still rapidly mcreasmy. Morphia half a grain; repeated at 3 P.M. and at 10 P.M.

28th.-8 A.M. : Comfortable night. Pulse 124, with temperature $99^{\circ}$. No sickness, vomiting, or pain. Again tapped abdomen till about half its natural size. Morphia half a grain.-2.30 P.M.: Pulse 112, morphia half a grain.-9.30 P.M. : Pulse 110 ; morphia half a grain.

29 th. - No sickness or pain. morning, afternoon, and evening two-thirds of a grain three times.

Oct. 1st.-More flatus. Morphia two-thirds of a grain three times.

Oct. 2nd.-Pulse 120; temperature $100 \cdot 2^{\circ}$. Much more flatus. A good deal of rumbling. The abdominal distension not increasing.

Between this date and Oct. 9th pulse varied from 120 to 106. Flatus passed occasionally. A little pain at times complained of. Thought on the 8th he could not recover. Given regularly three times every day two-thirds of a grain of morphia.

10th.-Felt sick. Had much pain in left side when he turned in bed. Morphia as before.

12th. - Felt like a large hard lump in left side, just above Poupart's ligament.

13 th. - Abdomen increasing again. Pulse 120 ; temperature 98. Much pain since 5 A.M. One grain of morphia three times a day.

14th, 15th, 16th, 17th, 18th.-Nothing particular to relate. One grain of morphia three times a day. Sometimes a little flatus, sometimes a very small quantity of black liquid fæces. 19th. - Two chambers nearly full of fæces, very liquid and black, passed. Such was the report I made to.day.

2lst. - More fæces. Morphia three times a day till Nov. 5th, gradually reducing the dose; from that day till the 24th twice a day, gradually reducing the quantity. As he complained of sickness of stomach and had bilious romit, I gave solution of hydrochlorate of ammonia and extract of taraxacum on and after Nov. 7th with much advantage, Temperature, as a rule, normal every day; pulse varying from 120 to 100

Dec. 4th.-The dark colour at length disappearing from the frees, now becoming more natural in appearance.

Dec. 3rd.-Only visit once daily and give morphia once. Motion nearly every day. Beginning to eat ; every thing he takes in small quantities.

25 th.-Had roast goose and potatoes for dinner.

Jan. 4th, 1880.-No occasion to visit.

I was apprehensive of malignant tumour in this case the history, the cachexy, the hard lump felt on the 12th Oct., all induced my thoughts to converge in this direction. The scybala removed by the injection on Tuesday Sept. 16th, were, I believe, in the rectum below the occlusion, and the small quantities of black fluid on the 17 th and 18th of Oct. were too insignificant to allow me to suppose the obstruction was removed. The copious discharge on the 19th was evidence unmistakable. To gain space I have contracted the above notes as much as I could from a full record kept regularly every day.

Liverpool.

\section{CASE WHERE A SET OF TEETH WITH PLATE REMAINED IN THE PHARYNX FOR TEN HOURS WITHOUT PRODUCING URGENT SYMPTOMS. BY DAVID CARLYLE, M.D.}

AT six o'clock in the evening of May 15th a messenger informed me that a widow, aged about fifty-five years, had been very poorly all day, but the symptoms he ascribed to her peculiar habits. He was in no way alarmed or anxious as to her state, so little, indeed, that I did not pay my visit for one hour after receiving the call. I saw her then about seven o'clock in the evening. No person was with her in the house; she was in bed lying on her right side. She made no complaint, nor were any symptoms of uneasiness or suffering indicated. I could obtain no information from her as to any illness; not in the least did she refer to her mouth or throat. I noticed an alteration in her speech, this being accompanied with a peculiar cluck. It was casually mentioned tuat her talse teeth were lust since the morning; she could give no information as to their vhereahouts during our conversation no cough, spasm, or suffering pointed to their situation. Examination along front of neck gave no information. I then got a tablespoon, the only convenient instrument, the handle bent down to nearly a right angle, to draw forward and depress the tongue for examination of pharynx. No foreign body then could be seen there; the effect, however, was beneficial, it induced much straining aud romiting. After these had subsided I again examined the pharynx with the spoon, and could then see the plate and teeth low in back of pharynx. The arch of the plate was upwards, and the roof or upper side of it towards vertebral column. With the tablespon and the aid of dressing forceps I was able to remove the plate of teeth without any difficulty. A man who lives in her house and some female neighbours knew that her teeth were lost, but had no sus. picion that they were in her throat; they state they were missing at nine in the morning; they were removed at seven in the evening (ten hours afterwards).

The case is remarkable from the patient being, as she states, unaware of the presence of the plate in the pharynx, and also from the small amount of suffering and inconvenience it induced.

Carlisle.

\section{REMARKABLE CASE OF FRACTURED FEMUR, RESULTING FROM MUSCULAR ACTION.}

\section{BY CLARENCE FOSTER, M.R.C.S.}

I wAS requested the other evening to visit a middle-aged gentleman, whom I found on my arrival to be suffering from simple transverse fracture of the left femur at its middle third. As is usual in this accident, there was considerable deformity, rendering the exact nature of the injury at once apparent. On inquiry I found the patient had neither fallen nor in any other way experienced direct violence to the limb, but, in walking across the floor, he unfortunately made a slight trip, and in endeavouring to maintain his equilibrium the sudden muscular action thereby induced caused the bone to snap asunder. The history of this case is at least remarkable, for although Debeaumarchef, Curet, and Léveillé have cited somewhat analogous instances, so eminent an authority as Richerend, in the fourth edition of his Surgical Nosography, vol. iii., p. 12, positively asserts that a long bone when healthy can never be broken by this means alone, and I have no reason whatever for supposing the existence of any abnormal condition of the part in this special patient.

Park-place, Leeds.

\section{A Aftirtor}

\section{HOSPITAL PRACTICE, BRITISH AND FOREIGN.}

Nulla autem est alia pro certo noscendi via, nisi quamplurimas et morbornm et dissection um historias, tum aliorum tum proprias collectas habere, et inter se comparare.-Morgagri De Sed. et Caus. Morb., lib. iv. Proømium.

\section{GREAT NORTHERN HOSPITAL.}

A CASE IN WHICH ONE-THIRD OF THE CRANIUM WAS DENUDED BY AN INJURY ; RECOVERY IN FIFTEIN DAYS.

(Under the care of Mr. W. SPENCER WATson.)

For the following notes we are indebted to Mr. Wharry, the house-surgeon.

Eliza $\mathrm{H}-$, a machinist, aged twenty-three years, was admitted on Feb. 5th, at 8 P.M., having thrown herself from a second-floor window (a height of about thirty feet) to escape from a fire. She seemed to have lost consciousness in the act of falling, but thought that she fell upon the body of another girl who had also precipitated herself from the same window. The whole of the posterior third of the scalp, 